\title{
Vitamin K: Double Bonds beyond Coagulation Insights into Differences between Vitamin K1 and K2 in Health and Disease
}

\author{
Maurice Halder ${ }^{1,+}$, Ploingarm Petsophonsakul ${ }^{2,+}$, Asim Cengiz Akbulut ${ }^{2,+}$, \\ Angelina Pavlic ${ }^{2,+} \mathbb{D}^{\mathbb{D}}$, Frode Bohan ${ }^{3}$, Eric Anderson ${ }^{3}$, Katarzyna Maresz ${ }^{4}$, \\ Rafael Kramann ${ }^{1}$ and Leon Schurgers ${ }^{1,2, *(D)}$ \\ 1 Division of Nephrology, RWTH Aachen University, 52074 Aachen, Germany; mhalder@ukaachen.de (M.H.); \\ rkramann@ukaachen.de (R.K.) \\ 2 Department of Biochemistry, Cardiovascular Research Institute Maastricht, 6200MD Maastricht, \\ The Netherlands; p.petsophonsakul@maastrichtuniversity.nl (P.P.); \\ a.akbulut@maastrichtuniversity.nl (A.C.A.); a.pavlic@maastrichtuniversity.nl (A.P.) \\ 3 NattoPharma ASA, 0283 Oslo, Norway; frode@nattopharma.com (F.B.); \\ eric.anderson@nattopharma.com (E.A.) \\ 4 International Science \& Health Foundation, 30-134 Krakow, Poland; katarzyna.maresz@nutricon.eu \\ * Correspondence: 1.schurgers@maastrichtuniversity.nl; Tel.: +31-43-3881680; Fax: +31-43-3884159 \\ + These authors contributed equally to this work.
}

Received: 24 January 2019; Accepted: 16 February 2019; Published: 19 February 2019

\begin{abstract}
Vitamin K is an essential bioactive compound required for optimal body function. Vitamin $\mathrm{K}$ can be present in various isoforms, distinguishable by two main structures, namely, phylloquinone (K1) and menaquinones (K2). The difference in structure between $\mathrm{K} 1$ and $\mathrm{K} 2$ is seen in different absorption rates, tissue distribution, and bioavailability. Although differing in structure, both act as cofactor for the enzyme gamma-glutamylcarboxylase, encompassing both hepatic and extrahepatic activity. Only carboxylated proteins are active and promote a health profile like hemostasis. Furthermore, vitamin K2 in the form of MK-7 has been shown to be a bioactive compound in regulating osteoporosis, atherosclerosis, cancer and inflammatory diseases without risk of negative side effects or overdosing. This review is the first to highlight differences between isoforms vitamin $\mathrm{K} 1$ and $\mathrm{K} 2$ by means of source, function, and extrahepatic activity.
\end{abstract}

Keywords: vitamin K1; vitamin K2; vitamin K dependent proteins; vascular calcification

\section{Introduction}

Vitamin K was first identified in 1936 to be a key factor in blood clotting. When chickens were fed a low-fat diet, they exhibited significantly lower coagulation capacity, resulting in severe bleeding [1]. The lipid fraction of diet was analyzed, and a novel antihemorrhagic factor was discovered. This lipid soluble factor was given the first letter in the alphabet available which coincided with the first letter of the German word "Koagulation" and deemed to be only essential for its anti-hemorrhagic trait [1]. Since then, non-coagulant functions have been discovered and have attracted research interest in several fields around the world. The vitamin $\mathrm{K}$ family is comprised of multiple similarly structured fat-soluble molecules containing a 2-methyl-1,4-naphthoquinone ring structure called menadione. Menadione (K3) is of synthetic origin, though due to reported adverse effects of hemolysis and liver toxicity will not encompass the scope of this review [2-4]. Naturally, vitamin K occurs as two vitamers: vitamin K1 (also known as phylloquinone) and vitamin K2 (designated also as menaquinones (MKs)). Phylloquinone contains a phytyl side chain which comprises 4 prenyl units [5]. Menaquinones 
contain an unsaturated aliphatic side chain with a variable number of prenyl units. The number of prenyl units indicates the respective type of menaquinone. Vitamin $\mathrm{K} 2$ can be divided into subtypes, namely, short-chain (i.e., menaquinone-4; MK-4) and long-chain (i.e., MK-7, MK-8, and MK-9). For K2, no official reference daily intake (RDI) exists at present. Nevertheless, the effects of K2 on improving health in cardiovascular disease (CVD), bone metabolism, chronic kidney disease and particular cancers has been subject to research in the last decades. The aim of this review is to signify and elaborate on the differences between $\mathrm{K} 1$ and $\mathrm{K} 2$, by source, and function with an emphasis on non-coagulant mechanisms of vitamin $\mathrm{K}$.

\section{Dietary Vitamin $K$}

Vitamin $\mathrm{K} 1$ is the predominant form of vitamin $\mathrm{K}$ present in the diet [6,7]. $\mathrm{K} 1$ is predominantly found in green vegetables and plant chlorophylls, whereas $\mathrm{K} 2$ menaquinones are synthesized by bacteria [8] and are primarily found in food where bacteria are part of the production process $[5,9]$. Major sources of K1 include spinach, cabbage, and kale, and absorption of dietary K1 is increased in presence of butter or oils. Beyond leafy greens, $\mathrm{K} 1$ can also be found in fruits like avocado, kiwi and grapes [10,11]. The main known sources of K2 are fermented food, meat, and dairy produce [12] (Figure 1). Fermentation of soy beans with Bacillus natto produces Natto, a Japanese dish that contains the highest content of K2, in particular MK-7 (321 ng/g of K1, and 10,985 ng/g of K2) [13]. Dairy products are the second richest source of K2 in the diet. Hard cheeses are considered to have the highest amount of menaquinones [14]. Other notable sources of K2 are chicken meat, egg yolks, sauerkraut, beef and salmon [12] (Figure 1).

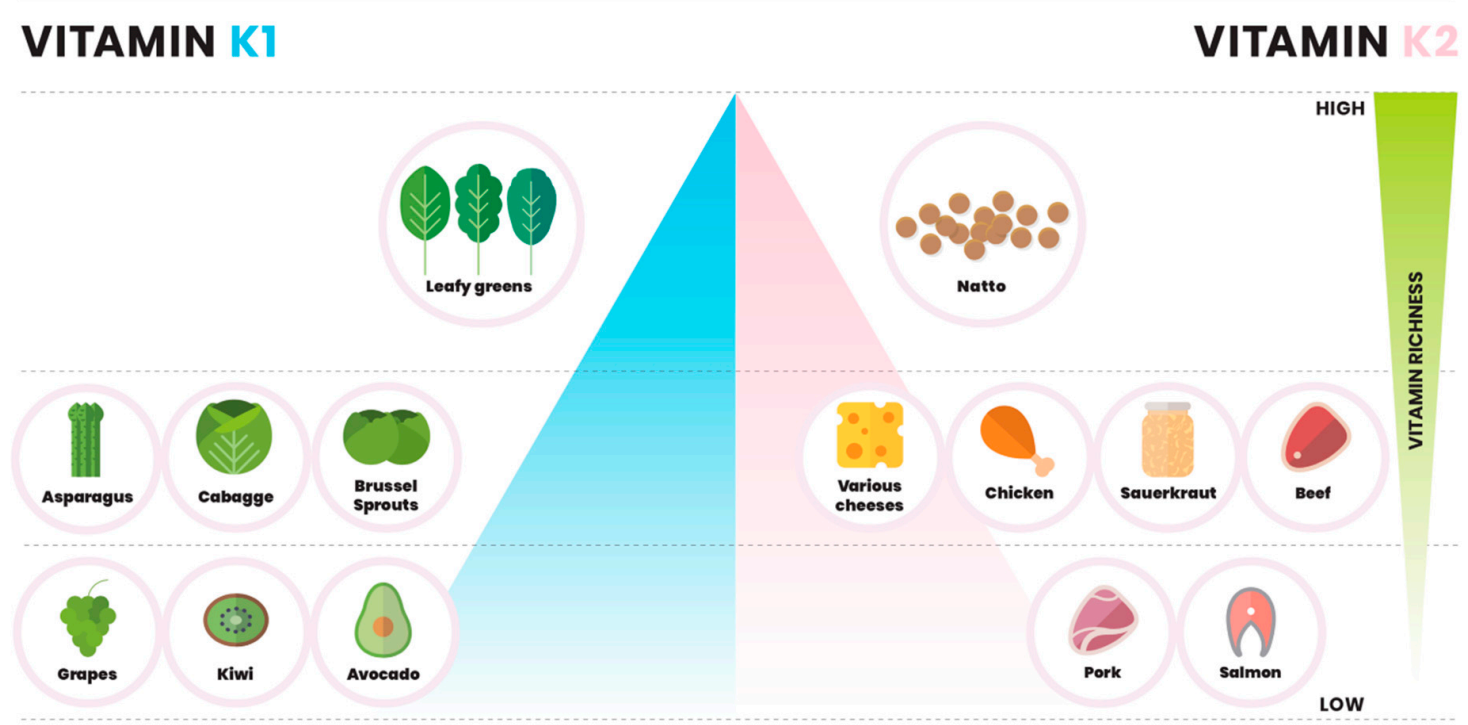

Figure 1. Dietary sources of vitamin K. Left side of pyramid displays K1 content gradient in dietary sources of vitamin K1. Leafy greens include spinach, kale and swiss shards. Right side visualizes K2 content gradient with natto being the most significant source. Various cheeses include hard and soft cheeses with $\mathrm{K} 2$ content being dependent on fermentation level.

\subsection{Vitamin $\mathrm{K}$ in Vegetables}

One of the best representatives in this group, containing both forms of vitamin $\mathrm{K}$, is sauerkraut (22.4 $\mu \mathrm{g}$ per $100 \mathrm{~g}$ of $\mathrm{K} 1$, and $5.5 \mu \mathrm{g}$ per $100 \mathrm{~g}$ of K2) [14]. Leafy green vegetables show the highest amount of vitamin K1. Vitamin K1 was present in collards (706 $\mu \mathrm{g}$ per $100 \mathrm{~g}$ ), in turnip ( $568 \mu \mathrm{g}$ per $100 \mathrm{~g})$, spinach $(96.7 \mu \mathrm{g}$ per $100 \mathrm{~g})$, kale $(75.3 \mu \mathrm{g}$ per $100 \mathrm{~g})$, broccoli $(146.7 \mu \mathrm{g}$ per $100 \mathrm{~g})$, soybeans roasted $(57.3 \mu \mathrm{g}$ per $100 \mathrm{~g})$, and carrot juice $(25.5 \mu \mathrm{g}$ per $100 \mathrm{~g})[7,15,16]$. 


\subsection{Vitamin K in Fruits and Nuts}

It has been shown by a US-led investigation that fruits and nuts do not generally contain K1, with the exception of kiwifruit (33.9-50.3 $\mu \mathrm{g}$ per $100 \mathrm{~g}$ ), avocado $(15.7-27.0 \mu \mathrm{g}$ per $100 \mathrm{~g}$ ), blueberries (14.7-27.2 $\mu \mathrm{g}$ per $100 \mathrm{~g}$ ), blackberries (14.7-25.1 ug per $100 \mathrm{~g})$, grapes red and green (13.8-18.1 $\mu \mathrm{g}$ per $100 \mathrm{~g})$, dried figs (11.4-20.0 $\mu \mathrm{g}$ per $100 \mathrm{~g}$ ) and dried prunes (51.1-68.1 $\mu \mathrm{g}$ per $100 \mathrm{~g})$. K1 was present in several nuts during this study; pine nuts (33.4-73.7 $\mu \mathrm{g}$ per $100 \mathrm{~g})$, cashews (19.4-64.3 $\mu \mathrm{g}$ per $100 \mathrm{~g}$ ), and pistachios (10.1-15.1 $\mu \mathrm{g}$ per $100 \mathrm{~g}$ ) [10]. Other fruit and nuts reported in the study contain vitamin $\mathrm{K} 1$ in insignificant traces. Further to this, vitamin $\mathrm{K}$ from fruit and nuts in the diet does not interfere with anticoagulation therapy in patients on warfarin [10].

\subsection{Vitamin K in Cheese}

Vitamin $\mathrm{K}$ content in cheese varies depending on a range of factors in production, such as time of ripening and regional differences. These dictate not only the type of cheese but fat and nutrient content. Typically, Dutch hard cheeses contain more K2 compared to softer Mediterranean cheeses. This is most likely influenced by duration of the fermentation process and the nature of bacterial strains used [14]. Although none of these cheeses can be considered an individual source of vitamin K2, consumption can contribute to total vitamin K levels [17]. Vitamin K1 and K2 were assessed in European cheeses and highest amount of K1 was found in Roquefort (6.56 $\mu \mathrm{g}$ per $100 \mathrm{~g})$, Pecorino (5.56 $\mu \mathrm{g}$ per $100 \mathrm{~g}$ ), Brie $(4.92 \mu \mathrm{g}$ per $100 \mathrm{~g})$, Boursin $(4.55 \mu \mathrm{g}$ per $100 \mathrm{~g})$, Norvegia $(4.37 \mu \mathrm{g}$ per $100 \mathrm{~g})$, Stilton $(3.62 \mu \mathrm{g}$ per $100 \mathrm{~g})$ [14]. Other tested cheeses contained less than $3 \mu \mathrm{g}$ per $100 \mathrm{~g}$. Total vitamin K2 was the highest

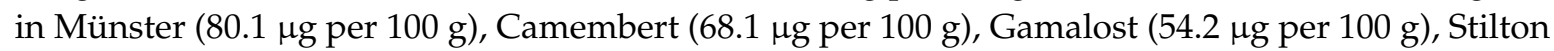

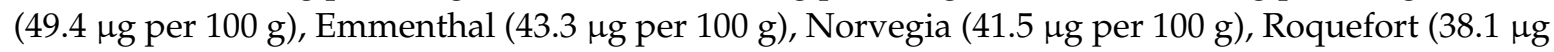
per $100 \mathrm{~g}$ ), and Raclette ( $32.3 \mu \mathrm{g}$ per $100 \mathrm{~g}$ ). The rest of examined cheeses comprised less than $3 \mu \mathrm{g}$ per $100 \mathrm{~g}$ of vitamin K2 [14].

\subsection{Vitamin K in Meat and Fish}

Vitamin $\mathrm{K}$ is present in meat and fish, although there are inconsistencies in the total content of vitamin $\mathrm{K}$ depending on the origin of the meat [15]. For example, the amount of MK-4 differs in chicken meat in the United States (13.6-31.6 $\mu \mathrm{g}$ per $100 \mathrm{~g}$ ), compared to the Netherlands (5.8-11.3 $\mu \mathrm{g}$ per $100 \mathrm{~g})$, and Japan $(27 \pm 15 \mu \mathrm{g}$ per $100 \mathrm{~g})$ [17]. In Europe, vitamin K1 is found in deer back $(2.4 \mu \mathrm{g}$ per $100 \mathrm{~g})$, beef liver $(2.3 \mu \mathrm{g}$ per $100 \mathrm{~g})$, and minced meat $(1.1 \mu \mathrm{g}$ per $100 \mathrm{~g})$ [14]. Values less than $0.5 \mu \mathrm{g}$ per $100 \mathrm{~g}$ were not deemed noteworthy for this review. The richest $\mathrm{K} 1$ fish sources are eel $(1.3 \mu \mathrm{g}$ per $100 \mathrm{~g})$ and mackerel $(0.5 \mu \mathrm{g}$ per $100 \mathrm{~g})$ [14].

Total vitamin K2 was present in meaningful concentrations in chicken meat (10.1 $\mu \mathrm{g}$ per $100 \mathrm{~g})$, beef liver $(11.2 \mu \mathrm{g}$ per $100 \mathrm{~g})$, minced meat $(7.6 \mu \mathrm{g}$ per $100 \mathrm{~g})$, beef meat $(1.9 \mu \mathrm{g}$ per $100 \mathrm{~g})$, and pork liver $(1.8 \mu \mathrm{g}$ per $100 \mathrm{~g})$ [14]. Only values above $1.5 \mu \mathrm{g}$ per $100 \mathrm{~g}$ for meat were chosen as representatives. Among the fish tested in this study, eel $(63.1 \mu \mathrm{g}$ per $100 \mathrm{~g})$ had the highest concentration of vitamin $\mathrm{K} 2$, followed by plaice $(5.3 \mu \mathrm{g}$ per $100 \mathrm{~g})$, mackerel $(0.6 \mu \mathrm{g}$ per $100 \mathrm{~g})$, and salmon $(0.6 \mu \mathrm{g}$ per $100 \mathrm{~g})$. The rest of the examined fish species contained less than $0.5 \mu \mathrm{g}$ per $100 \mathrm{~g}$ of vitamin $\mathrm{K} 1$ and total vitamin K2 [14].

\section{Adequate Intake is an Estimate}

Vitamin K content can vary depending on the approach used for detection, especially in the case of $\mathrm{K} 2$. The gold standard for measuring vitamin $\mathrm{K}$ is by high-performance liquid chromatography (HPLC) using C-18 reversed phase column and fluorometric detection after post-column zinc reduction. This technique is used frequently to analyze vitamin $\mathrm{K}$ content in food and enables quantification of separate vitamin K isoforms. For example, a European standard method (EN 14148:2003) was developed to determine vitamin K1 by HPLC; however, no official registered method exists for K2. Typical recommended vitamin K intake in North America varies from 50 to as high as $600 \mu \mathrm{g} /$ day 
for vitamin K1, and from 5 to $600 \mu \mathrm{g}$ /day for vitamin K2 [12]. The challenge lies in assessing an adequate intake, as current requirement is an estimate based on regional consumption. Currently, daily recommended intake for vitamin $\mathrm{K}$ is-based solely on intake of vitamin K1, blood coagulation and differs by region [18-20]. It is defined as the median of daily intake in healthy individuals and differs worldwide. According to National Academy of Medicine (NAM), previously known as the Institute of Medicine, the required vitamin K dosage for adult men is $120 \mu \mathrm{g} /$ day and $90 \mu \mathrm{g} /$ day for women. According to the World Health Organization (WHO) and the Food and Agriculture Organization (FAO), the dosage is $65 \mu \mathrm{g} /$ day for men and $55 \mu \mathrm{g} /$ day for women, on the basis of $1 \mu \mathrm{g} /$ day $/ \mathrm{kg}$ vitamin $\mathrm{K}$. The Commission of the European Communities sets a RDI for vitamin K of $75 \mu \mathrm{g} /$ day [12,21-23]. In case of vitamin K1, NAM implies that the average intake is currently already higher than adequate (surpassing 100\%) [22]. Therefore, daily recommended intake of vitamin K1 can be achieved easily by the Western diet, as no deficiency in vitamin K1 has been reported so far in healthy adults [12]. However, intake of vitamin K2 from food corresponds to only $25 \%$ and $5 \%$ of the total vitamin K intake, respectively [21]. Therefore, administration of K2 via supplements in a high dosage might be advisable for meeting the required daily intake for improvement of overall health [12].

\section{Functions of Vitamin K1 and K2}

The most well-known function of vitamin $\mathrm{K}$ is as a cofactor in the activation of vitamin K-dependent coagulations factors [24,25]. Through post translational modification of glutamate (Glu) residues in coagulation factors, vitamin K enables posttranslational carboxylation, which allows high affinity binding with support of calcium to negatively charged phospholipid membrane areas and therefore maintains hemostasis [26-28].

Due to well-established guidelines, vitamin $\mathrm{K} 1$ is also administered as a medication. For instance, newborns are given $1 \mathrm{mg} \mathrm{K} 1$ shortly after birth to prevent the potentially lethal vitamin K deficiency bleeding (VKDB). VKDB occurring within the first 24 hours of life is uncommon and is usually caused by drugs prescribed to the mother. These may interfere with fetal vitamin K metabolism [29]. Without prophylaxis, VKDB can occur within the first week after birth due to vitamin K deficiency caused by insufficient placental transfer and low concentrations in breast milk of vitamin $\mathrm{K}$ [30,31]. Moreover, vitamin K1 is used as an antagonist in patients on vitamin K Antagonist (VKA) treatment prior to elective surgery or when international normalized ratio (INR) values are too high (prolonged bleeding) [32,33].

Other functions of vitamin $\mathrm{K}$ are mainly ascribed to vitamin K2 (discussed below). Different strains of bacteria synthesize a variety of menaquinones, the exception being MK-4. MK-4 is a product of tissue specific conversion from phylloquinone, and can be found in mammals [34]. Nakagawa et al. identified UbiA prenyltransferase containing 1 (UBIAD1), a human homologue of Escherichia coli prenyltransferase, responsible for the conversion of phylloquinone to MK-4 in several tissues such as the cerebrum, liver and pancreas [35]. The discovery of a MK-4 biosynthetic enzyme in humans and confirmation that MK-4 originates from phylloquinone might support the rationale behind a lower efficacy of MK-4 compared to other menaquinones.

\section{Vitamin K: The Vitamin K Cycle}

Both vitamin $\mathrm{K} 1$ and $\mathrm{K} 2$ can function as cofactors in the carboxylation process of vitamin $\mathrm{K}$-dependent proteins (VKDPs). Given this, vitamin K serves as a cofactor for $\gamma$-glutamylcarboxylase (GGCX), which catalyzes the Glu residue of VKDPs into $\gamma$-carboxyglutamic acid (Gla). This process is driven by the oxidation of vitamin $\mathrm{K}$-hydroquinone $\left(\mathrm{KH}_{2}\right)$ to vitamin $\mathrm{K}$-epoxide $(\mathrm{KO})$ in the vitamin $\mathrm{K}$ cycle. The vitamin K-oxidoreductase (VKOR) converts $\mathrm{KO}$ to vitamin $\mathrm{K}$ and back to $\mathrm{KH}_{2}$, generating a recycling process of vitamin $\mathrm{K}[36,37]$. Consequently, VKAs inhibit VKOR and thereby the recycling of vitamin $\mathrm{K}$ resulting in a drug-induced vitamin $\mathrm{K}$ deficiency [38]. 
VKDPs are categorized as hepatic and extra-hepatic VKDPs. Hepatic VKDPs include coagulation factors II, VII, IX, X, and anticoagulant protein C, protein S, and protein Z, all of which are involved in regulating blood coagulation. Extra-hepatic VKDPs include Matrix Gla protein (MGP), Osteocalcin, and Gla-rich protein (GRP) [36]. These VKDPs are primarily involved in maintaining bone homeostasis, as well as inhibiting ectopic calcification [39]. MGP is primarily expressed in vascular smooth muscle cells and chondrocytes. This protein is known to inhibit extracellular matrix mineralization of vascular lesions and is involved in vascular remodeling [40-42]. Osteocalcin can be defined as a bone tissue-specific protein and is involved in regulating mineral deposition [36,43]. GRP can be found in calcified cartilage and vasculature, where it directly binds and inhibits crystal formation/maturation and vascular smooth muscle cell calcification $[36,44,45]$.

In addition to the role of vitamin $\mathrm{K}$ in the carboxylation of VKDPs, recent studies have suggested a role for vitamin $\mathrm{K}$ as an antioxidant. A paralogue enzyme of VKORC1, named VKORC1-like 1 (VKORC1L1), is expressed in many tissues. VKORC1L1 has been shown to mediate vitamin $\mathrm{K}$-dependent intracellular antioxidant function in the human cellular membrane [46]. Indeed, vitamin $\mathrm{KH}_{2}$ exhibits an antioxidative activity of 10- to 100-fold higher than any other known radical scavengers, such as alpha-tocopherol and ubiquinone [47]. Vitamin K protects the cellular membrane from lipid peroxidation [48]. This antioxidative activity is diminished in the presence of warfarin. Both vitamin $\mathrm{K} 1$ and $\mathrm{K} 2$ prevent oxidative stress in neuronal cells and primary oligodendrocytes through inhibition of 12-Lipoxygenase [49,50]. In addition to antioxidative properties, vitamin $\mathrm{K}$ has been reported to facilitate ATP generation and rescue mitochondrial dysfunction [51].

\section{Vitamin K: Bioavailability}

Of all the menaquinones, MK-7 is absorbed most efficiently and exhibits greatest bioavailability [6,13]. This was shown by a comparative study between $\mathrm{K} 1$ and MK-7 following intake of vegetables and $\mathrm{K} 2$ rich food, respectively. Both vitamin $\mathrm{K} 1$ and MK-7 were readily absorbed within 2 hours after ingestion. However, postprandial serum concentrations of K2 (MK-7) were 10-fold higher than K1 [6]. K1 showed large interindividual variation in fasting plasma concentrations [52]. Vitamin K1 also showed inferior absorption in comparison to MK-4, as well as longer chain menaquinone food sources (MK-8 and MK-9) [6]. Long chain menaquinones, such as MK-7 and MK-9, have longer half-life in circulation in comparison to K1 (Figure 2) [53]. Thus, it is available for longer in the circulation to be absorbed by extrahepatic tissue [13]. However, not all menaquinones are equally well absorbed. The bioavailability of MK-4 does not reflect an increased serum concentration after administration. However, MK-7 administration is reflected in increased serum MK-7 levels up to several days, thereby contributing to vitamin K status [54]. Finally, MK-9, being even more lipophilic, has a very long half-life, but due to the lipophilicity is poorly absorbed [53].

\section{Vitamin K: Uptake and Distribution}

All vitamin $\mathrm{K}$ forms can be taken up by enterocytes in the small intestine and packaged into chylomicrons during absorption. These chylomicrons are then taken up by the liver. Moreover, vitamin $\mathrm{K} 1$ has a rapid removal rate from the circulation. This was revealed by giving isotope-labeled phylloquinone to a volunteer, which then showed rapid appearance of radiolabeled excretory metabolites in urine and bile [55,56]. Vitamin K1 is preferentially retained in the liver to assist carboxylation of clotting factors [53]. In contrast, vitamin K2, particularly long chain derivatives, are redistributed to the circulation and are available for extra-hepatic tissues such as bone and vasculature (Figure 2) [5,53]. 


\section{BIOAVAILABILITY OF VITAMIN K}

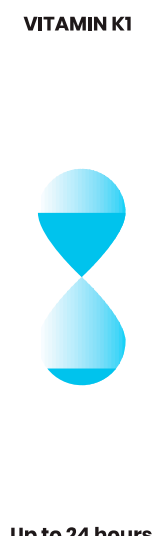

Up to 24 hours

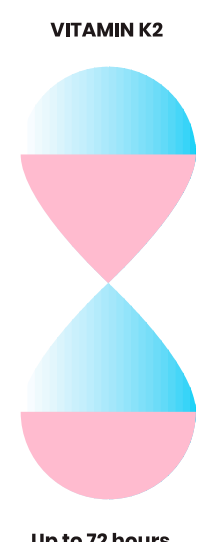

Up to 72 hours

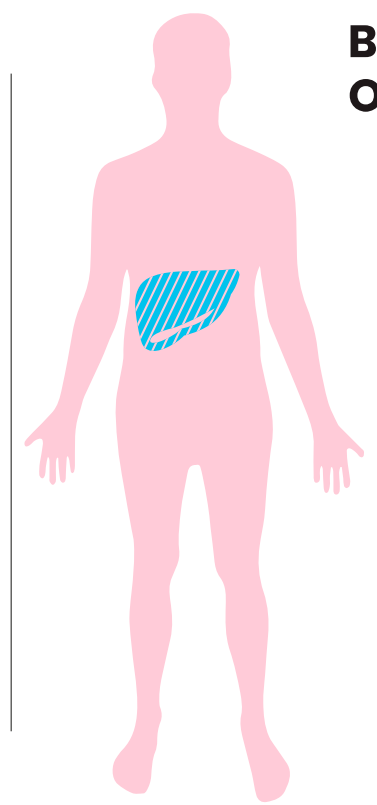

\section{BIODISTRIBUTION OF VITAMIN K}

ITAMIN K1

VITAMIN K2

Figure 2. Bioavailability and biodistribution of vitamin K. Vitamin K2 has a longer half-life in the circulation than vitamin $\mathrm{K} 1$. While vitamin $\mathrm{K} 1$ is retained and exerts its function in the liver, vitamin $\mathrm{K} 2$ is redistributed to the circulation and (extra-)hepatic tissues.

\section{Vitamin $\mathrm{K} 2$ in Health and Disease}

Vitamin K2-dependent proteins are expressed in a varying manner in both soft and hard tissues. The role of $\mathrm{K} 1$ in coagulation is well established and has been reviewed elsewhere. Whereas vitamin K2's position in health and disease is well recognized within CVD, bone development and fractures, chronic kidney disease and certain cancers. Additional evidence is demonstrating further roles of vitamin $\mathrm{K} 2$ in liver disease, immune function, neurological diseases and obesity.

\subsection{Vitamin K2: Cardiovascular Disease}

Vascular calcification is an active process that causes CVD, the largest killer in the world [57]. It is well known that vitamin $\mathrm{K} 2$-dependent proteins activate a protective mechanism preventing the development of vascular calcification [58]. Furthermore, vitamin K2, in the form of MK-7, has been proven in numerous trials with healthy and diseased patient cohorts to have a long-term protective effect on the development of calcification [59-62]. Additionally, several studies have demonstrated an overall reduction in risk of CVD development [63]. Even a regression of arterial stiffening and improvement of vascular elasticity have been observed in healthy population cohorts following supplementation. Interestingly, in a study investigating all vitamin K1 and $\mathrm{K} 2$ isoforms, only $\mathrm{K} 2$ was effective and beneficial for CVD health and not K1 [64]. Furthermore, the role of K2 in CVD is profound and detailed discussion can be found elsewhere $[58,59,65]$. At present, there are multiple large clinical studies being performed around the world with vitamin K2 supplementation in a variety of cardiovascular patients, the results of which will add further substance to the role of vitamin $\mathrm{K} 2$ in CVD [66].

\subsection{Vitamin K2: Bone Fractures and Degeneration}

Bone fracture and quality is important in any aged population. Vitamin K2 is known to improve bone quality, which in turn reduces fracture risk as demonstrated by numerous studies with population groups above the age of 50 [67-70]. Furthermore, children are inherently born vitamin K2 deficient, and there is the implication that should this not be corrected, inadequate bone formation might take place [71]. This is substantiated by mutations to vitamin K-dependent enzymes, resulting in birth defects that affect development of bone and cartilage [72]. Within bone marrow mesenchymal stem 
cells, vitamin K2 treatment supports osteogenic differentiation [73]. Osteocalcin expression in bone is related to proper function, although the precise mechanism is under ongoing research [58]. Further to this, there are population studies currently underway that will shed further light on the role of vitamin $\mathrm{K} 2$ on bone development, health and maintenance [74,75].

\subsection{Vitamin K2: Diabetes Mellitus}

Long-term supplementation of vitamin K2 has been shown to reduce the risk of diabetes development. The largest study, with 38,000 men and women, aged 20-70, demonstrated that just $10 \mu \mathrm{g} /$ day of K2 decreases diabetes risk by 7\% [76]. The mechanism by which this K2 may act in doing so is beginning to be unraveled. Vitamin $\mathrm{K} 2$ activates osteocalcin, which has been shown in vitro to promote proliferation of pancreatic beta cells as well as increasing insulin production and expression of CyclinD1 [77-79]. The specific mechanism is currently under research and it is hypothesized that osteocalcin, lectin and adiponectin have an intricate network for glucose metabolism that can be modulated by vitamin $\mathrm{K} 2$ [80].

\subsection{Vitamin K2: Cancer}

Interestingly, vitamin $\mathrm{K} 2$ has been explored in several clinical interventions to supplement cancer treatments [81]. In vitro studies found K2 supplementation alone to prevent growth and metastasis of multiple cancer cell lines [82-84]. The mechanisms by which vitamin K2 can inhibit proliferation and metastasis of cancers has been reviewed elsewhere [80]. In short, vitamin K2 may act in several pathways including protein kinase $\mathrm{A}$, protein kinase $\mathrm{C}$, nuclear factor kappa B and steroid and xenobiotic receptor [81,85]. Furthermore, there are multiple cases by which K2 supplementation alongside standard treatment subsided cancer development, including multiple cases where patients entered complete remission [86,87]. Remarkably vitamin K2's action as an anticancer agent is not limited to a definitive cancer type, and instead has been reported in multiple cancer forms [81].

\subsection{Vitamin K2: Liver Disease}

The role of vitamin $\mathrm{K}$ in the liver has been well established with regards to production of coagulation factors and activation of VKDPs $[88,89]$. While the majority of research has focused on K1, $\mathrm{K} 2$ has a higher bioactivity, and might act in a similar manner to hepatic tissue. Additionally, emerging vitamin K2 research is demonstrating a regenerative effect on oval cells, as well as maturation of hepatic cells from stem cell cultures $[90,91]$. This suggests that there might be a developmental importance of K2 in the liver. Furthermore, within the anticancer effects of vitamin K2 several trials have found MK-4 to be an effective agent against hepato-carcinomas that have arisen from alcoholic and non-alcoholic liver cirrhosis [85,92]. Moreover, there is a positive trend in vitamin K2 supplementation in treating liver cirrhosis, although further investigation is required to determine whether this is significant and to understand the mechanism by which vitamin $\mathrm{K} 2$ acts in liver disease.

\subsection{Vitamin K2: Chronic Kidney Disease}

Status of dephosphorylated-uncarboxylated-MGP (dp-ucMGP) is an accepted research marker for vitamin $\mathrm{K}$ deficiency first described in patients with chronic kidney disease [93]. Dp-ucMGP is associated with progression of CKD, being that later-stage CKD patients have higher circulating dp-ucMGP levels [94-97]. Vitamin K2 supplementation has been shown to improve renal artery function and prevent further development of renal artery calcification [62,98]. This is of overall benefit to renal function. Further to this, it has been demonstrated that vitamin K2 supplementation may improve glomerular filtration in a patient cohort [96]. The promise of vitamin K2 in CKD research is great and there are multiple large-scale studies underway using vitamin $\mathrm{K}$ supplementation to treat patients with CKD [74,99-101]. 


\subsection{Vitamin K2: The Immune System}

In recent years, ex vivo studies have demonstrated a previously unknown immunomodulatory role for vitamin K2. First, it was demonstrated that MK-7 modulated expression of TNF- $\alpha$, IL- $1 \alpha$ and IL-1 $\beta$ [102]. Furthering this finding, K2 decreases proliferation of T-cells from healthy individuals, whereas vitamin $\mathrm{K} 1$ had no such effect [103]. This has been further substantiated with T-cells from a larger number of children with pediatric atopic dermatitis and healthy controls, as well as a separate study with patients on dialysis $[104,105]$. Both these studies demonstrated that K2 decreased the number of activated T-cells, as well as proliferation. Thus, accumulated evidence is showing a novel role of $\mathrm{K} 2$ as an immunosuppressive agent. This needs to be further elaborated; until then, a novel physiological mechanism by which vitamin $\mathrm{K} 2$ can aid immunomodulation can be hypothesized, although it requires further study.

\subsection{Vitamin K2: Neurological Disease}

Extrahepatic activity of vitamin $\mathrm{K} 2$ has been elucidated in vivo by varying activity of $\mathrm{K} 2$ recycling enzymes in different tissues. Prominently, a subset of vitamin K2 enzymes have been shown to be highly expressed in the brain [106]. A protective effect of $\mathrm{K} 2$ on neurons in vitro has been documented [107]. MK-4 improved energy production and rescued PINK1 mutation found in Parkinson's disease [51]. More recently, research identified vitamin K2 protection of neurons via a novel mechanism involving P38 MAP kinase pathway [108]. Further to this, various K2 analogs have been found to be decisive in neuronal differentiation [109]. The first epidemiological study of K2 in relation to neuronal activity involved a cohort of 45 patients with multiple sclerosis (MS) and 29 healthy volunteers [110]. K2 levels were greatly reduced in patients with MS compared to the controls that were gender and age dependent. Also, K2 levels were correlated with neurological spasms and lesions of the optic nerves. These emerging studies suggest a potentially important role for vitamin $\mathrm{K} 2$ in neurological development and disease.

\subsection{Vitamin K2: Obesity}

The link between osteocalcin and adiponectin has been strongly suggested; however, the mode by which any such action takes place remains elusive $[78,111,112]$. Direct elevation of uncarboxylated osteocalcin (ucOC) levels reduced fat mass and improved glucose metabolism in mice $[79,113]$. More recently, supplementation of vitamin K1 and MK-4 in rats reduced total fat and serum triglyceride levels [114]. Further to this, a mechanism was implicated by Ding et al., whereby VKORC1L1 was found to promote adipogenesis [115]. Consequently, downregulation of VKORC1L1 increased intracellular K2 levels, and preadipocyte differentiation was inhibited [115]. Human cohort studies have shown improvements in body weight, waist circumference, body composition, visceral fat and diabetes mellitus from K2 supplementation [116-119]. This all suggests an overall beneficial effect of vitamin $\mathrm{K} 2$ on glucose and fat metabolism that requires further investigation to confirm.

\section{Conclusions and Future Perspective}

The existence of vitamin $\mathrm{K}$ has been known for over 80 years, namely via its essential role in coagulation. The discovery of different isoforms of vitamin $\mathrm{K}$ is beginning to elucidate a significant role of vitamin $\mathrm{K}$ outside of coagulation. Functions of $\mathrm{K} 2$ are proving to be beneficial with regard to CVD and bone metabolism. There is a growing body of evidence suggesting vitamin K2 is involved in multiple cellular processes, and might have a protective role in various organs throughout the human body (Figure 3). While vitamin K2 has improved outcomes in many clinical trials, the exact mechanism of action remains to be unraveled. Major health organizations, such as WHO, European Food Safety Authority (EFSA) and Food and Drug Administration (FDA) have established RDI for vitamin $\mathrm{K}$, which is solely based on the dose of $\mathrm{K} 1$ to retain an appropriate blood clotting function. This review highlights and summarizes differences between vitamin $\mathrm{K} 1$ and $\mathrm{K} 2$ in intake and function. 
When exploring the non-coagulation, extrahepatic activity of vitamin $\mathrm{K}$, it is clear that $\mathrm{K} 2$ in its various forms is the highlight of such activity. Therefore, although history and nomenclature have classed K1 and $\mathrm{K} 2$ into the same category, these molecules can have a very different action in the body. Though a new realm to vitamin $\mathrm{K}$ seems to be on the horizon, whether it opens up new answers in health and disease remains to be seen. Differences between $\mathrm{K} 1$ and $\mathrm{K} 2$ merit recognition among national and international regulatory organizations, and remain open to research.

\section{FUNCTIONS OF VITAMIN IN THE BODY}

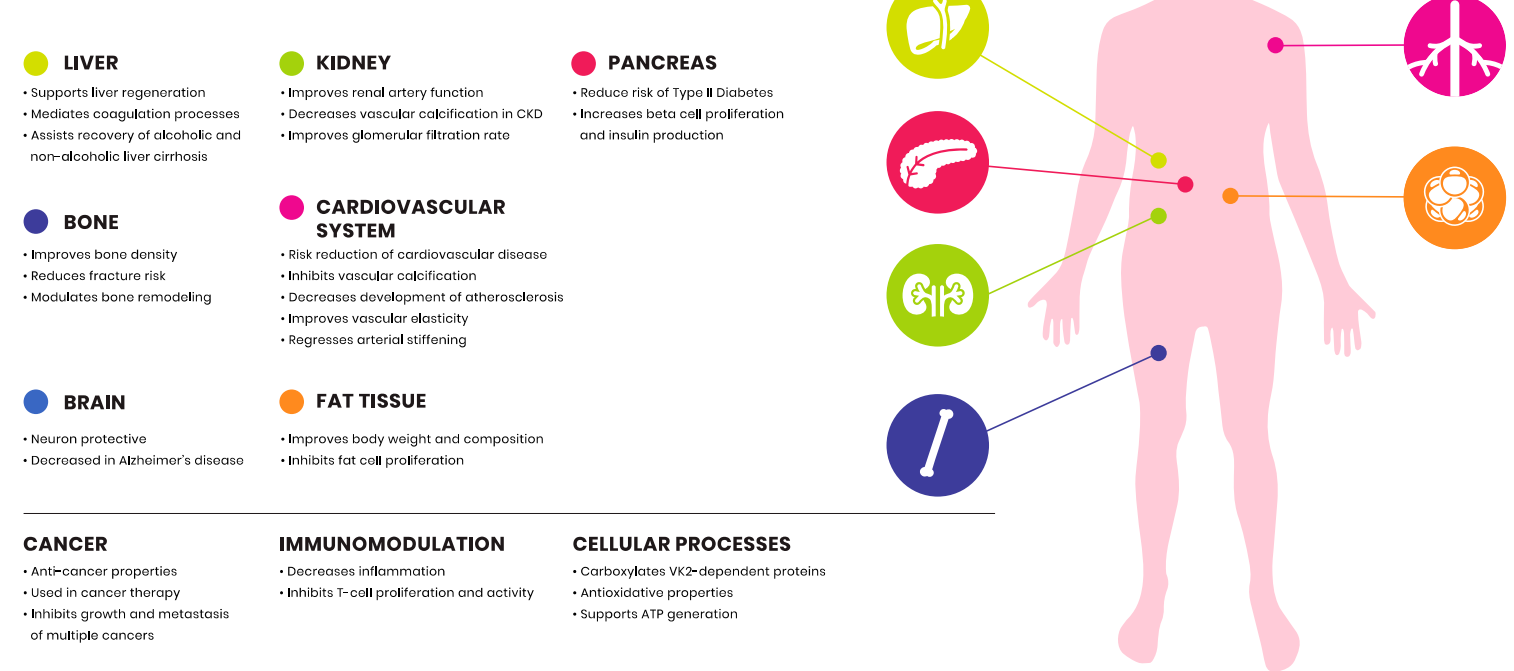

Figure 3. Functions of vitamin K2 in the body. Vitamin K2 exerts protective role and is involved in various organ systems throughout the human body (summarized in the figure).

Funding: Research from M.H., A.C.A., R.K. and L.J.S. is in part funded via the European Union's Horizon 2020 research and innovation programme under the Marie Skłodowska-Curie grant agreement No 722609. Research from P.P., A.P., and L.J.S. is in part funded via the European Union's Horizon 2020 research and innovation programme under the Marie Skłodowska-Curie grant agreement No 675111. R.K. received support from the Germany Research Foundation (DFG), SFB TRR219, TP C05.

Acknowledgments: We thank Nutricon.eu for help with graphics.

Conflicts of Interest: Frode Bohan and Eric Anderson are employed by NattoPharma ASA, which is industrial partner of the Marie Skłodowska-Curie grants No 722609 and No 675111.

\section{References}

1. Dam, H.; Schønheyder, F. The occurrence and chemical nature of vitamin K. Biochem. J. 1936, 30, 897-901. [CrossRef] [PubMed]

2. Shenkin, A. Dietary reference values for vitamin A, vitamin K, arsenic, boron, chromium, copper, iodine, iron, manganese, molybdenum, nickel, silicon, vanadium and zinc. J. Hum. Nutr. Diet. 2003, 16, 199-200. [CrossRef]

3. Schwalfenberg, G.K. Vitamins K1 and K2: The Emerging Group of Vitamins Required for Human Health. J. Nutr. Metab. 2017, 2017, 6254836. [CrossRef] [PubMed]

4. Gröber, U.; Reichrath, J.; Holick, M.F.; Kisters, K. Vitamin K: An old vitamin in a new perspective. Dermato-Endocrinology 2015, 6, e968490.

5. Shearer, M.J.; Newman, P. Metabolism and cell biology of vitamin K. Thromb. Haemost. 2017, 100, 530-547.

6. Schurgers, L.J.; Vermeer, C. Determination of Phylloquinone and Menaquinones in Food. Pathophysiol. Haemost. Thromb. 2001, 30, 298-307. [CrossRef] [PubMed]

7. Gijsbers, B.L.M.G.; Jie, K.-S.G.; Vermeer, C. Effect of food composition on vitamin K absorption in human volunteers. Br. J. Nutr. 2007, 76, 223-229. [CrossRef] 
8. Bentley, R.; Meganathan, R. Biosynthesis of vitamin K (menaquinone) in bacteria. Microbiol. Rev. 1982, 46, 241-280.

9. Booth, S.L. Vitamin K: Food composition and dietary intakes. Food Nutr. Res. 2017, 56, 5505. [CrossRef]

10. Dismore, M.L.; Haytowitz, D.B.; Gebhardt, S.E.; Peterson, J.W.; Booth, S.L. Vitamin K content of nuts and fruits in the US diet. J. Am. Diet. Assoc. 2003, 103, 1650-1652. [CrossRef]

11. Tarento, T.D.C.; McClure, D.D.; Talbot, A.M.; Regtop, H.L.; Biffin, J.R.; Valtchev, P.; Dehghani, F.; Kavanagh, J.M. A potential biotechnological process for the sustainable production of vitamin K 1. Crit. Rev. Biotechnol. 2018, 69, 1-19. [CrossRef]

12. Marles, R.J.; Roe, A.L.; Oketch-Rabah, H.A. US Pharmacopeial Convention safety evaluation of menaquinone-7, a form of vitamin K. Nutr. Rev. 2017, 75, 553-578. [CrossRef] [PubMed]

13. Schurgers, L.J.; Teunissen, K.J.F.; Hamulyák, K.; Knapen, M.H.J.; Vik, H.; Vermeer, C. Vitamin K-containing dietary supplements: Comparison of synthetic vitamin K1 and natto-derived menaquinone-7. Blood 2007, 109, 3279-3283. [CrossRef] [PubMed]

14. Vermeer, C.; Raes, J.; van t Hoofd, C.; Knapen, M.; Xanthoulea, S. Menaquinone Content of Cheese. Nutrients 2018, 10, 446. [CrossRef] [PubMed]

15. Elder, S.J.; Haytowitz, D.B.; Howe, J.; Peterson, J.W.; Booth, S.L. Vitamin K Contents of Meat, Dairy, and Fast Food in the U.S. Diet. J. Agric. Food Chem. 2006, 54, 463-467. [CrossRef] [PubMed]

16. US Department of Agriculture, Agricultural Research Service, Nutrient Data Laboratory. USDA National Nutrient Database for Standard Reference, Release 27. Version Current: May 2015. Available online: http:/ / www.ars.usda.gov/ba/bhnrc/ndl (accessed on 10 January 2019).

17. Walther, B.; Karl, J.P.; Booth, S.L.; Boyaval, P. Menaquinones, Bacteria, and the Food Supply: The Relevance of Dairy and Fermented Food Products to Vitamin K Requirements. Adv. Nutr. 2013, 4, 463-473. [CrossRef] [PubMed]

18. Australian National Health and Medical Research Council, New Zealand Ministry of Health. Vitamin K. Nutrient Reference Values for Australia and New Zealand; Commonwealth of Australia: Canberra, Australia, 2005; pp. 147-151.

19. FAO Rome Food and Nutrition Division. Vitamin K. Human Vitamin and Mineral Requirements: Report of a Joint FAO/WHO Expert Consultation, Bangkok, Thailand; FAO: Rome, Italy, 2001; pp. 133-150.

20. National Research Council. Dietary Reference Intakes for Vitamin A, Vitamin K, Arsenic, Boron, Chromium, Copper, Iodine, Iron, Manganese, Molybdenum, Nickel, Silicon, Vanadium, and Zinc; National Academy Press: Washington, DC, USA, 2000.

21. Beulens, J.W.J.; Booth, S.L.; van den Heuvel, E.G.H.M.; Stoecklin, E.; Baka, A.; Vermeer, C. The role of menaquinones (vitamin K2) in human health. Br. J. Nutr. 2013, 110, 1357-1368. [CrossRef] [PubMed]

22. World Health Organization and Food and Agriculture Organization of the United Nations. Vitamin K. In Vitamin and Mineral Requirements in Human Nutrition, 2nd ed.; World Health Organization: Geneva, Switzerland, 2004; pp. 108-129.

23. Commission of the European Communities. Commission Directive 2008/100/EC of 28 October 2008 Amending Council Directive 90/496/EEC on Nutrition Labelling for Food Stuffs as Regards Recommended Daily Allowances, Energy Conversion Factors and Definitions. Available online: http:/ / eur-lex.europa.eu/legal-content/EN/TXT/? uri $\frac{1}{4}$ celex\%3A32008L0100 (accessed on 26 July 2016).

24. Olson, R. The Function and Metabolism of Vitamin K. Annu. Rev. Nutr. Annu. Rev. 1984, 4, $281-337$. [CrossRef]

25. Danziger, J. Vitamin K-dependent Proteins, Warfarin, and Vascular Calcification. Clin. J. Am. Soc. Nephrol. 2008, 3, 1504-1510. [CrossRef]

26. Nelsestuen, G.L.; Suttie, J.W. Mode of action of vitamin K. Calcium binding properties of bovine prothrombin. Biochemistry 2002, 11, 4961-4964. [CrossRef]

27. Ellison, E.H.; Castellino, F.J. Adsorption of Vitamin K-Dependent Blood Coagulation Proteins To Spread Phospholipid Monolayers as Determined from Combined Measurements of the Surface Pressure and Surface Protein Concentration. Biochemistry 1998, 37, 7997-8003. [CrossRef] [PubMed]

28. Schurgers, L.; Spronk, H. Differential cellular effects of old and new oral anticoagulants: Consequences to the genesis and progression of atherosclerosis. Thromb. Haemost. 2017, 112, 909-917.

29. Shearer, M.J. Vitamin K deficiency bleeding (VKDB) in early infancy. Blood Rev. 2009, 23, 49-59. [CrossRef] [PubMed] 
30. Burke, C.W. Vitamin K Deficiency Bleeding: Overview and Considerations. J. Pediatr. Health Care 2013, 27, 215-221. [CrossRef] [PubMed]

31. Greer, F.R. Vitamin K the basics-What's new? Early Hum. Dev. 2010, 86, 43-47. [CrossRef] [PubMed]

32. Wilson, S.E.; Watson, H.G.; Crowther, M.A. Low-dose oral vitamin K therapy for the management of asymptomatic patients with elevated international normalized ratios: A brief review. CMAJ 2004, 170, 821-824. [CrossRef] [PubMed]

33. Burbury, K.L.; Milner, A.; Snooks, B.; Jupe, D.; Westerman, D.A. Short-term warfarin reversal for elective surgery-using low-dose intravenous vitamin K: Safe, reliable and convenient. Br. J. Haematol. 2011, 154, 626-634. [CrossRef] [PubMed]

34. Okano, T.; Shimomura, Y.; Yamane, M.; Suhara, Y.; Kamao, M.; Sugiura, M.; Nakagawa, K. Conversion of phylloquinone (Vitamin K1) into menaquinone-4 (Vitamin K2) in mice: Two possible routes for menaquinone-4 accumulation in cerebra of mice. J. Biol. Chem. 2008, 283, 11270-11279. [CrossRef] [PubMed]

35. Nakagawa, K.; Hirota, Y.; Sawada, N.; Yuge, N.; Watanabe, M.; Uchino, Y.; Okuda, N.; Shimomura, Y.; Suhara, Y.; Okano, T. Identification of UBIAD1 as a novel human menaquinone-4 biosynthetic enzyme. Nature 2010, 468, 117-121. [CrossRef] [PubMed]

36. Willems, B.A.G.; Vermeer, C.; Reutelingsperger, C.P.M.; Schurgers, L.J. The realm of vitamin K dependent proteins: Shifting from coagulation toward calcification. Mol. Nutr. Food Res. 2014, 58, 1620-1635. [CrossRef] [PubMed]

37. van Gorp, R.; Schurgers, L. New Insights into the Pros and Cons of the Clinical Use of Vitamin K Antagonists (VKAs) Versus Direct Oral Anticoagulants (DOACs). Nutrients 2015, 7, 9538-9557. [CrossRef]

38. Stafford, D.W. The vitamin K cycle. J. Thromb. Haemost. 2005, 3, 1873-1878. [CrossRef] [PubMed]

39. Hauschka, P.V.; Lian, J.B.; Gallop, P.M. Direct identification of the calcium-binding amino acid, gamma-carboxyglutamate, in mineralized tissue. Proc. Natl. Acad. Sci. USA 1975, 72, 3925-3929. [CrossRef] [PubMed]

40. Luo, G.; Ducy, P.; McKee, M.D.; Pinero, G.J.; Loyer, E.; Behringer, R.R.; Karsenty, G. Spontaneous calcification of arteries and cartilage in mice lacking matrix GLA protein. Nature 1997, 386, 78-81. [CrossRef] [PubMed]

41. Murshed, M.; Schinke, T.; McKee, M.D.; Karsenty, G. Extracellular matrix mineralization is regulated locally; different roles of two gla-containing proteins. J. Cell Biol. 2004, 165, 625-630. [CrossRef] [PubMed]

42. Schurgers, L.J.; Teunissen, K.J.F.; Knapen, M.H.J.; Kwaijtaal, M.; van Diest, R.; Appels, A.; Reutelingsperger, C.P.; Cleutjens, J.P.; Vermeer, C. Novel conformation-specific antibodies against matrix gamma-carboxyglutamic acid (Gla) protein: Undercarboxylated matrix Gla protein as marker for vascular calcification. Arter. Thromb. Vasc. Biol. 2005, 25, 1629-1633. [CrossRef] [PubMed]

43. Neve, A.; Corrado, A.; Cantatore, F.P. Osteoblast physiology in normal and pathological conditions. Cell Tissue Res. 2010, 343, 289-302. [CrossRef] [PubMed]

44. Viegas, C.S.B.; Rafael, M.S.; Enriquez, J.L.; Teixeira, A.; Vitorino, R.; Luis, I.M.; Costa, R.M.; Santos, S.; Cavaco, S.; Neves, J.; et al. Gla-Rich Protein Acts as a Calcification Inhibitor in the Human Cardiovascular System. Arter. Thromb. Vasc. Biol. 2015, 35, 399-408. [CrossRef] [PubMed]

45. Willems, B.A.; Furmanik, M.; Caron, M.M.J.; Chatrou, M.L.L.; Kusters, D.H.M.; Welting, T.J.M.; Stock, M.; Rafael, M.S.; Viegas, C.S.B.; Simes, D.C.; et al. Ucma/GRP inhibits phosphate-induced vascular smooth muscle cell calcification via SMAD-dependent BMP signalling. Sci. Rep. 2018, 8, 4961. [CrossRef] [PubMed]

46. Westhofen, P.; Watzka, M.; Marinova, M.; Hass, M.; Kirfel, G.; Müller, J.; Bevans, C.G.; Müller, J.; Oldenburg, J. Human Vitamin K 2,3-Epoxide Reductase Complex Subunit 1-like 1 (VKORC1L1) Mediates Vitamin K-dependent Intracellular Antioxidant Function. J. Biol. Chem. 2011, 286, 15085-15094. [CrossRef] [PubMed]

47. Mukai, K.; Morimoto, H.; Kikuchi, S.; Nagaoka, S.-I. Kinetic study of free-radical-scavenging action of biological hydroquinones (reduced forms of ubiquinone, vitamin $\mathrm{K}$ and tocopherol quinone) in solution. Biochim. Biophys. Acta (BBA) 1993, 1157, 313-317. [CrossRef]

48. Vervoort, L.M.; Ronden, J.E.; Thijssen, H.H. The potent antioxidant activity of the vitamin K cycle in microsomal lipid peroxidation. Biochem. Pharm. 1997, 54, 871-876. [CrossRef]

49. Wang, H.; Li, J.; Follett, P.L.; Zhang, Y.; Cotanche, D.A.; Jensen, F.E.; Volpe, J.J.; Rosenberg, P.A. 12-Lipoxygenase plays a key role in cell death caused by glutathione depletion and arachidonic acid in rat oligodendrocytes. Eur. J. Neurosci. 2004, 20, 2049-2058. [CrossRef] [PubMed]

50. Li, J.; Wang, H.; Rosenberg, P.A. Vitamin K prevents oxidative cell death by inhibiting activation of 12-lipoxygenase in developing oligodendrocytes. J. Neurosci. Res. 2009, 87, 1997-2005. [CrossRef] [PubMed] 
51. Vos, M.; Esposito, G.; Edirisinghe, J.N.; Vilain, S.; Haddad, D.M.; Slabbaert, J.R.; van Meensel, S.; Schaap, O.; De Strooper, B.; Meganathan, R.; et al. Vitamin K2 Is a Mitochondrial Electron Carrier That Rescues Pink1 Deficiency. Science 2012, 336, 1306-1310. [CrossRef] [PubMed]

52. Booth, S.L.; Tucker, K.L.; McKeown, N.M.; Davidson, K.W.; Dallal, G.E.; Sadowski, J.A. Relationships between Dietary Intakes and Fasting Plasma Concentrations of Fat-Soluble Vitamins in Humans. J. Nutr. 1997, 127, 587-592. [CrossRef] [PubMed]

53. Schurgers, L.J.; Vermeer, C. Differential lipoprotein transport pathways of K-vitamins in healthy subjects. Biochim. Biophys. Acta (BBA) 2002, 1570, 27-32. [CrossRef]

54. Sato, T.; Schurgers, L.J.; Uenishi, K. Comparison of menaquinone-4 and menaquinone-7 bioavailability in healthy women. Nutr. J. 2012, 11, 120. [CrossRef]

55. Shearer, M.J.; Mallinson, C.N.; Webster, G.R.; Barkhan, P. Clearance from Plasma and Excretion in Urine, Faeces and Bile of an Intravenous Dose of Tritiated Vitamin K 1in Man. Br. J. Haematol. 1972, 22, 579-588. [CrossRef]

56. Shearer, M.; Barkhan, P. Studies on the metabolites of phylloquinone (vitamin K1) in the urine of man. Biochim. Biophys. Acta (BBA) 1973, 297, 300-312. [CrossRef]

57. Schurgers, L.J.; Akbulut, A.C.; Kaczor, D.M.; Halder, M.; Koenen, R.R.; Kramann, R. Initiation and Propagation of Vascular Calcification Is Regulated by a Concert of Platelet- and Smooth Muscle Cell-Derived Extracellular Vesicles. Front. Cardiovasc. Med. 2018, 5, 14391. [CrossRef] [PubMed]

58. Wen, L.; Chen, J.; Duan, L.; Li, S. Vitamin K-dependent proteins involved in bone and cardiovascular health (Review). Mol. Med. Rep. 2018, 18, 3-15. [CrossRef] [PubMed]

59. Barrett, H.; O'Keeffe, M.; Kavanagh, E.; Walsh, M.; O'Connor, E. Is Matrix Gla Protein Associated with Vascular Calcification? A Systematic Review. Nutrients 2018, 10, 415. [CrossRef] [PubMed]

60. Knapen, M.H.J.; Braam, L.A.J.L.M.; Drummen, N.E.; Bekers, O.; Hoeks, A.P.G.; Vermeer, C. Menaquinone-7 supplementation improves arterial stiffness in healthy postmenopausal women. A double-blind randomised clinical trial. Thromb. Haemost. 2015, 113, 1135-1144. [CrossRef] [PubMed]

61. Knapen, M.H.J.; Drummen, N.E.; Smit, E.; Vermeer, C.; Theuwissen, E. Three-year low-dose menaquinone-7 supplementation helps decrease bone loss in healthy postmenopausal women. Osteoporos. Int. 2013, 24, 2499-2507. [CrossRef] [PubMed]

62. Westenfeld, R.; Krueger, T.; Schlieper, G.; Cranenburg, E.C.M.; Magdeleyns, E.J.; Heidenreich, S.; Holzmann, S.; Vermeer, C.; Jahnen-Dechent, W.; Ketteler, M.; et al. Effect of Vitamin K2 Supplementation on Functional Vitamin K Deficiency in Hemodialysis Patients: A Randomized Trial. Am. J. Kidney Dis. 2012, 59, 186-195. [CrossRef] [PubMed]

63. Gast, G.C.M.; de Roos, N.M.; Sluijs, I.; Bots, M.L.; Beulens, J.W.J.; Geleijnse, J.M.; Witteman, J.C.; Grobbee, D.E.; Peeters, P.H.; van der Schouw, Y.T. A high menaquinone intake reduces the incidence of coronary heart disease. Nutr. Metab. Cardiovasc. Dis. 2009, 19, 504-510. [CrossRef]

64. Geleijnse, J.M.; Vermeer, C.; Grobbee, D.E.; Schurgers, L.J.; Knapen, M.H.J.; van der Meer, I.M.; Hofman, A.; Witteman, J.C. Dietary intake of menaquinone is associated with a reduced risk of coronary heart disease: The Rotterdam Study. J. Nutr. 2004, 134, 3100-3105. [CrossRef]

65. DiNicolantonio, J.J.; Bhutani, J.; O’Keefe, J.H. The health benefits of vitamin K. Open Heart 2015, 2 , e000300. [CrossRef]

66. Brandenburg, V.M.; Schurgers, L.J.; Kaesler, N.; Püsche, K.; van Gorp, R.H.; Lefthériotis, G.; Reinartz, S.; Koos, R.; Krüger, T. Prevention of vasculopathy by vitamin K supplementation: Can we turn fiction into fact? Atherosclerosis 2015, 240, 10-16. [CrossRef]

67. Iwamoto, J.; Sato, Y.; Takeda, T.; Matsumoto, H. High-dose vitamin K supplementation reduces fracture incidence in postmenopausal women: A review of the literature. Nutr. Res. 2009, 29, 221-228. [CrossRef]

68. Bulló, M.; Estruch, R.; Salas-Salvadó, J. Dietary vitamin K intake is associated with bone quantitative ultrasound measurements but not with bone peripheral biochemical markers in elderly men and women. Bone 2011, 48, 1313-1318. [CrossRef] [PubMed]

69. Evatt, M.L. High Prevalence of Hypovitaminosis D Status in Patients With Early Parkinson Disease. Arch. Neurol. 2011, 68, 314-319. [CrossRef] [PubMed]

70. Apalset, E.M.; Gjesdal, C.G.; Eide, G.E.; Tell, G.S. Intake of vitamin K1 and K2 and risk of hip fractures: The Hordaland Health Study. Bone 2011, 49, 990-995. [CrossRef] [PubMed] 
71. Prynne, C.J.; Thane, C.W.; Prentice, A.; Wadsworth, M. Intake and sources of phylloquinone (vitamin K1) in 4-year-old British children: Comparison between 1950 and the 1990s. Public Health Nutr. 2007, 8, 389. [CrossRef]

72. Rashdan, N.A.; Rutsch, F.; Kempf, H.; Váradi, A.; Lefthériotis, G.; MacRae, V.E. New perspectives on rare connective tissue calcifying diseases. Curr. Opin. Pharmacol. 2016, 28, 14-23. [CrossRef] [PubMed]

73. Zhang, Y.; Weng, S.; Yin, J.; Ding, H.; Zhang, C.; Gao, Y. Vitamin K2 promotes mesenchymal stem cell differentiation by inhibiting miR-133a expression. Mol. Med. Rep. 2017, 15, 2473-2480. [CrossRef] [PubMed]

74. Effect of Vitamin K2 (MK7) on Cardiovascular and Bone Disease in Dialysis Patients. Available online: https: / ClinicalTrials.gov/show / NCT02976246 (accessed on 10 January 2019).

75. Vitamin K as Additive Treatment in Osteoporosis. Available online: https://ClinicalTrials.gov/show/ NCT01232647 (accessed on 10 January 2019).

76. Beulens, J.W.J.; van der, A.D.L.; Grobbee, D.E.; Sluijs, I.; Spijkerman, A.M.W.; van der Schouw, Y.T. Dietary Phylloquinone and Menaquinones Intakes and Risk of Type 2 Diabetes. Diabetes Care 2010, 33, 1699-1705. [CrossRef] [PubMed]

77. Booth, S.L.; Centi, A.; Smith, S.R.; Gundberg, C. The role of osteocalcin in human glucose metabolism: Marker or mediator? Nat. Rev. Endocrinol. 2012, 9, 43-55. [CrossRef]

78. Lee, N.K.; Sowa, H.; Hinoi, E.; Ferron, M.; Ahn, J.D.; Confavreux, C.; Dacquin, R.; Mee, P.J.; McKee, M.D.; Jung, D.Y. Endocrine Regulation of Energy Metabolism by the Skeleton. Cell 2007, 130, 456-469. [CrossRef] [PubMed]

79. Ferron, M.; Hinoi, E.; Karsenty, G.; Ducy, P. Osteocalcin differentially regulates $\beta$ cell and adipocyte gene expression and affects the development of metabolic diseases in wild-type mice. Proc. Natl. Acad. Sci. USA 2008, 105, 5266-5270. [CrossRef] [PubMed]

80. Li, Y.; Chen, J.P.; Duan, L.; Li, S. Effect of vitamin K2 on type 2 diabetes mellitus: A review. Diabetes Res. Clin. Pract. 2018, 136, 39-51. [CrossRef] [PubMed]

81. Xv, F.; Chen, J.; Duan, L.; Li, S. Research progress on the anticancer effects of vitamin K2 (Review). Oncol. Lett. 2018, 15, 8926-8934. [CrossRef] [PubMed]

82. Xia, J.; Matsuhashi, S.; Hamajima, H.; Iwane, S.; Takahashi, H.; Eguchi, Y.; Mizuta, T.; Fujimoto, K.; Kuroda, S.; Ozaki, I. The role of PKC isoforms in the inhibition of NF-kB activation by vitamin K2 in human hepatocellular carcinoma cells. J. Nutr. Biochem. 2012, 23, 1668-1675. [CrossRef]

83. Showalter, S.L.; Wang, Z.; Costantino, C.L.; Witkiewicz, A.K.; Yeo, C.J.; Brody, J.R.; Carr, B.I. Naturally occurring $\mathrm{K}$ vitamins inhibit pancreatic cancer cell survival through a caspase-dependent pathway. J. Gastroenterol. Hepatol. 2010, 25, 738-744. [CrossRef] [PubMed]

84. Enomoto, M.; Tsuchida, A.; Miyazawa, K.; Yokoyama, T.; Kawakita, H.; Tokita, H.; Naito, M.; Itoh, M.; Ohyashiki, K.; Aoki, T. Vitamin K2-induced cell growth inhibition via autophagy formation in cholangiocellular carcinoma cell lines. Int. J. Mol. Med. 2007, 20, 801-808. [CrossRef] [PubMed]

85. Jinghe, X. Vitamin K and hepatocellular carcinoma: The basic and clinic. World J. Clin. Cases 2015, 3, 757-764. [CrossRef] [PubMed]

86. Sada, E.; Abe, Y.; Ohba, R.; Tachikawa, Y.; Nagasawa, E.; Shiratsuchi, M.; Takayanagi, R. Vitamin K2 modulates differentiation and apoptosis of both myeloid and erythroid lineages. Eur. J. Haematol. 2010, 85, 538-548. [CrossRef] [PubMed]

87. Yaguchi, M.; Miyazawa, K.; Katagiri, T.; Nishimaki, J.; Kizaki, M.; Tohyama, K.; Toyama, K. Vitamin K2 and its derivatives induce apoptosis in leukemia cells and enhance the effect of all-trans retinoic acid. Leukemia 1997, 11, 779-787. [CrossRef] [PubMed]

88. Lisman, T.; Porte, R.J. Pathogenesis, prevention, and management of bleeding and thrombosis in patients with liver diseases. Res. Pract. Thromb. Haemost. 2017, 1, 150-161. [CrossRef] [PubMed]

89. Shah, N.L.; Intagliata, N.M.; Northup, P.G.; Argo, C.K.; Caldwell, S.H. Procoagulant therapeutics in liver disease: A critique and clinical rationale. Nat. Rev. Gastroenterol. Hepatol. 2014, 11, 675-682. [CrossRef] [PubMed]

90. Lin, M.; Sun, P.; Zhang, G.; Xu, X.; Liu, G.; Miao, H.; Yang, Y.; Xu, H.; Zhang, L.; Wu, P.; et al. Vitamin K2-Enhanced Liver Regeneration is Associated with Oval Cell Expansion and Up-Regulation of Matrilin-2 Expression in 2- AAF/PH Rat Model. Curr. Mol. Med. 2014, 14, 361-369. [CrossRef] [PubMed] 
91. Avior, Y.; Levy, G.; Zimerman, M.; Kitsberg, D.; Schwartz, R.; Sadeh, R.; Moussaieff, A.; Cohen, M.; Itskovitz-Eldor, J.; Nahmias, Y. Microbial-derived lithocholic acid and vitamin $\mathrm{K} 2$ drive the metabolic maturation of pluripotent stem cells-derived and fetal hepatocytes. Hepatology 2015, 62, 265-278. [CrossRef] [PubMed]

92. Zhong, J.H.; Mo, X.S.; Xiang, B.D.; Yuan, W.P.; Jiang, J.F.; Xie, G.S.; Li, L.Q. Postoperative Use of the Chemopreventive Vitamin K2 Analog in Patients with Hepatocellular Carcinoma. PLoS ONE 2013, 8, e58082. [CrossRef] [PubMed]

93. Kurnatowska, I.; Grzelak, P.; Masajtis-Zagajewska, A.; Kaczmarska, M.; Stefańczyk, L.; Vermeer, C.; Maresz, K.; Nowicki, M. Plasma Desphospho-Uncarboxylated Matrix Gla Protein as a Marker of Kidney Damage and Cardiovascular Risk in Advanced Stage of Chronic Kidney Disease. Kidney Blood Press. Res. 2016, 41, 231-239. [CrossRef] [PubMed]

94. Puzantian, H.; Akers, S.R.; Oldland, G.; Javaid, K.; Miller, R.; Ge, Y.; Ansari, B.; Lee, J.; Suri, A.; Hasmath, Z.; et al. Circulating Dephospho-Uncarboxylated Matrix Gla-Protein Is Associated With Kidney Dysfunction and Arterial Stiffness. Am. J. Hypertens. 2018, 31, 988-994. [CrossRef]

95. Wei, F.-F.; Drummen, N.E.A.; Schutte, A.E.; Thijs, L.; Jacobs, L.; Petit, T.; Yang, W.Y.; Smith, W.; Zhang, Z.Y.; $\mathrm{Gu}$, Y.M.; et al. Vitamin K Dependent Protection of Renal Function in Multi-ethnic Population Studies. EBioMedicine 2016, 4, 162-169. [CrossRef]

96. Wei, F.F.; Trenson, S.; Thijs, L.; Huang, Q.F.; Zhang, Z.Y.; Yang, W.Y.; Moliterno, P.; Allegaert, K.; Boggia, J.; Janssens, S.; et al. Desphospho-uncarboxylated matrix Gla protein is a novel circulating biomarker predicting deterioration of renal function in the general population. Nephrol. Dial. Transplant. 2017, 33, 1122-1128. [CrossRef]

97. Aoun, M.; Makki, M.; Azar, H.; Matta, H.; Chelala, D.N. High Dephosphorylated-Uncarboxylated MGP in Hemodialysis patients: Risk factors and response to vitamin K2, A pre-post intervention clinical trial. BMC Nephrol. 2017, 18, 948. [CrossRef]

98. Caluwe, R.; Vandecasteele, S.; Van Vlem, B.; Vermeer, C.; De Vriese, A.S. Vitamin K2 supplementation in haemodialysis patients: A randomized dose-finding study. Nephrol. Dial. Transplant. 2014, 29, 1385-1390. [CrossRef]

99. Vitamin $\mathrm{K}$ to Attenuate Coronary Artery Calcification in Hemodialysis Patients. Available online: https:/ / ClinicalTrials.gov / show/NCT01528800 (accessed on 10 January 2019).

100. Vitamin K1 to Slow Progression of Vascular Calcification in HD Patients. Available online: https: / ClinicalTrials.gov / show / NCT01742273 (accessed on 10 January 2019).

101. Effect on Vascular Calcification of Replacing Warfarin by Rivaroxaban With or Without VitK2 in Hemodialysis Patients. Available online: https:/ /ClinicalTrials.gov/show / NCT02610933 (accessed on 10 January 2019).

102. Pan, M.H.; Maresz, K.; Lee, P.S.; Wu, J.C.; Ho, C.T.; Popko, J.; Mehta, D.S.; Stohs, S.J.; Badmaev, V. Inhibition of TNF- $\alpha$, IL- $1 \alpha$, and IL-1 $\beta$ by Pretreatment of Human Monocyte-Derived Macrophages with Menaquinone-7 and Cell Activation with TLR Agonists In Vitro. J. Med. Food 2016, 19, 663-669. [CrossRef]

103. Myneni, V.D.; Mezey, E. Immunomodulatory effect of vitamin K2: Implications for bone health. Oral Dis. 2018, 24, 67-71. [CrossRef]

104. Kusano, J.; Tanaka, S.; Matsuda, H.; Hara, Y.; Fujii, Y.; Suzuki, S.; Sekiyama, M.; Ando, E.; Sugiyama, K.; Hirano, T. Vitamin K1 and Vitamin K2 immunopharmacological effects on the peripheral lymphocytes of healthy subjects and dialysis patients, as estimated by the lymphocyte immunosuppressant sensitivity test. J. Clin. Pharm. Ther. 2018, 18, 590. [CrossRef]

105. Meng, K.; Xu, W.; Miura, T.; Suzuki, S.; Chiyotanda, M.; Tanaka, S.; Sugiyama, K.; Kawashima, H.; Hirano, T. The effects of vitamin $\mathrm{K} 1$ and vitamin $\mathrm{K} 2$ on the proliferation, cytokine production and regulatory T-cell frequency in peripheral blood mononuclear cells of paediatric atopic dermatitis patients. Exp. Dermatol. 2018, 114, 6. [CrossRef] [PubMed]

106. Caspers, M.; Czogalla, K.J.; Liphardt, K.; Müller, J.; Westhofen, P.; Watzka, M.; Oldenburg, J. Two enzymes catalyze vitamin $\mathrm{K}$ 2,3-epoxide reductase activity in mouse: VKORC1 is highly expressed in exocrine tissues while VKORC1L1 is highly expressed in brain. Thromb. Res. 2015, 135, 977-983. [CrossRef]

107. Sakaue, M.; Mori, N.; Okazaki, M.; Kadowaki, E.; Kaneko, T.; Hemmi, N.; Sekiguchi, H.; Maki, T.; Ozawa, A.; Hara, S.; et al. Vitamin $\mathrm{K}$ has the potential to protect neurons from methylmercury-induced cell death In Vitro. J. Neurosci. Res. 2011, 89, 1052-1058. [CrossRef] [PubMed] 
108. Hadipour, E.; Tayarani-Najaran, Z.; Fereidoni, M. Vitamin K2 protects PC12 cells against A $\beta$ (1-42) and H $2 \mathrm{O}$ 2-induced apoptosis via p38 MAP kinase pathway. Nutr. Neurosci. 2018, 1, 1-10. [CrossRef] [PubMed]

109. Kimura, K.; Hirota, Y.; Kuwahara, S.; Takeuchi, A.; Tode, C.; Wada, A.; Osakabe, N.; Suhara, Y. Synthesis of Novel Synthetic Vitamin K Analogues Prepared by Introduction of a Heteroatom and a Phenyl Group That Induce Highly Selective Neuronal Differentiation of Neuronal Progenitor Cells. J. Med. Chem. 2017, 60, 2591-2596. [CrossRef]

110. Lasemi, R.; Kundi, M.; Moghadam, N.B.; Moshammer, H.; Hainfellner, J.A. Vitamin K2 in multiple sclerosis patients. Wien. Klin. Wochenschr. 2018, 130, 307-313. [CrossRef]

111. Shiba, S.; Ikeda, K.; Azuma, K.; Hasegawa, T.; Amizuka, N.; Horie-Inoue, K.; Inoue, S. $\gamma$-Glutamyl carboxylase in osteoblasts regulates glucose metabolism in mice. Biochem. Biophys. Res. Commun. 2014, 453, 350-355. [CrossRef]

112. Ferron, M.; Lacombe, J.; Germain, A.; Oury, F.; Karsenty, G. GGCX and VKORC1 inhibit osteocalcin endocrine functions. J. Cell Biol. 2015, 208, 761-776. [CrossRef]

113. Ferron, M.; McKee, M.D.; Levine, R.L.; Ducy, P.; Karsenty, G. Intermittent injections of osteocalcin improve glucose metabolism and prevent type 2 diabetes in mice. Bone 2012, 50, 568-575. [CrossRef]

114. Sogabe, N.; Maruyama, R.; Baba, O.; Hosoi, T.; Goseki-Sone, M. Effects of long-term vitamin K1 (phylloquinone) or vitamin K2 (menaquinone-4) supplementation on body composition and serum parameters in rats. Bone 2011, 48, 1036-1042. [CrossRef]

115. Ding, Y.; Cui, J.; Wang, Q.; Shen, S.; Xu, T.; Tang, H.; Han, M.; Wu, X. The Vitamin K Epoxide Reductase Vkorc111 Promotes Preadipocyte Differentiation in Mice. Obesity 2018, 87, 377. [CrossRef] [PubMed]

116. Juanola-Falgarona, M.; Salas-Salvadó, J.; Estruch, R.; Portillo, M.P.; Casas, R.; Miranda, J.; Martinez-González, M.A.; Bulló, M. Association between dietary phylloquinone intake and peripheral metabolic risk markers related to insulin resistance and diabetes in elderly subjects at high cardiovascular risk. Cardiovasc. Diabetol. 2013, 12, 7. [CrossRef]

117. Shea, M.K.; Booth, S.L.; Gundberg, C.M.; Peterson, J.W.; Waddell, C.; Dawson-Hughes, B.; Saltzman, E. Adulthood Obesity Is Positively Associated with Adipose Tissue Concentrations of Vitamin K and Inversely Associated with Circulating Indicators of Vitamin K Status in Men and Women. J. Nutr. 2010, 140, 1029-1034. [CrossRef] [PubMed]

118. Knapen, M.H.J.; Jardon, K.M.; Vermeer, C. Vitamin K-induced effects on body fat and weight: Results from a 3-year vitamin K2 intervention study. Eur. J. Clin. Nutr. 2017, 72, 136-141. [CrossRef]

119. Tamura, T.; Yoneda, M.; Yamane, K.; Nakanishi, S.; Nakashima, R.; Okubo, M.; Kohno, N. Serum leptin and adiponectin are positively associated with bone mineral density at the distal radius in patients with type 2 diabetes mellitus. Metabolism 2007, 56, 623-628. [CrossRef] [PubMed]

(C) 2019 by the authors. Licensee MDPI, Basel, Switzerland. This article is an open access article distributed under the terms and conditions of the Creative Commons Attribution (CC BY) license (http://creativecommons.org/licenses/by/4.0/). 